\section{Philip Ifeakachukwu Nwosa}

(iD) https://orcid.org/0000-0001-6073-6659

Department of Economics

Faculty of Social Sciences

Federal University Oye-Ekiti, Nigeria

philip.nwosa@fuoye.edu.ng

\section{Semira Olajumoke Tijani}

Department of Economics

Faculty of Social Sciences

Federal University Oye-Ekiti, Nigeria

tijanisemira@yahoo.com

\title{
Government expenditure and service sector growth in Nigeria
}

Accepted by Editor Ewa Ziemba | Received: August 3, 2019 | Revised: February 27, 2020; March 17, 2020 | Accepted: March 24, 2020.

\begin{abstract}
Aim/purpose - This study aims at examining the contribution of government expenditure on service sector growth in Nigeria for the period 1970 to 2017. The service sector and government intervention are vital to economic growth of any country, hence this study.

Design/methodology/approach - The study utilised the co-integration and the error correction modelling techniques. The study also conducted the stationarity tests.

Findings - The regression estimates showed that government expenditure had negative and significant impact of service sector growth in Nigeria.

Research implications/limitations - The implication of the findings of this study is that government expenditure over the years has not contributed positively to enhance the growth of the service sector; the study therefore recommends the need for completion of various abandoned and on-going infrastructural projects, such as road construction, water provision and electrification projects, which are vital to the growth of the service sector. Moreover, the government can through the monetary authority issue directives deposit money in banks to give loans at a reduced interest rate to investors in the service sector.
\end{abstract}

Originality/value/contribution - This study has been able to show that there is the need for greater financial commitment of the government in order to improve the growth of the service sector.

Keywords: government expenditure, service sector performance, co-integration, OLS. JEL Classification: H54. 


\section{Introduction}

Since the emergence of the Keynesian theoretical perspective on macroeconomic management, government expenditure has been an important instrument in regulating and spurring the economy on the desired growth path both in the developing and developed countries. With the underdeveloped nature of the financial structure and poor instrument of monetary policy, government expenditure has been a vital macroeconomic management in developing countries such as Nigeria. Government expenditure on indices of human capital development promotes human knowledge, productivity and national output. In addition, government expenditure on infrastructures - power supply, accessible roads and markets, good communication network, among others, enhances production activities and reduces its associated costs. Government expenditure on the economy also acts as incentives which attract private sector investment, thereby increasing the level of aggregate investment and consequently promotes economic growth (Al-Yousif, 2000; Cooray, 2009; Ranjan \& Sharma, 2008).

The service sector of any nation has been described as the lifeline for the socio-economic growth of the economy. Also known as the tertiary sector it is the third of the three traditional economic sectors (others are the primary and secondary sectors). The service sector is a major employer of labour in any country which involves the production of services instead of end products. The transportation, financial, education and information and telecommunication subsectors of the service sector have contributed to the enhancement of productive activities of the other sectors and the aggregate economy as a whole, while the human health and social services, public administration, accommodation and food service subsectors contribute to improving the social well-being of a country's labour force. The presence of a well functioning service sector also promotes investment climate among others (Cali, Ellis, \& te Velde, 2008). In the light of the above, the service sector has emerged as the fastest growing sector and in some countries the largest contributor to real gross domestic product (Table A1 in appendix).

With respect to Nigeria, the government has encouraged investment in the service sector through various liberalisation reforms in the power, financial, transport and communication sub-sectors among others. While the growth of the service sector could be said to be on an increase as observed in Figure 1, the growth potential of the sector has been limited by inadequate power supply and other infrastructural facilities, high cost of production, inadequate skilled manpower and raw material, and political and economic instability. The sharp in- 
crease in the growth of the service sector in recent times can be attributed to the policy reforms of the President Obasanjo administration between 1999 and 2008 . This policy reform brought about the growth of the transport and communication sub-sector through the establishment of mobile telecommunication companies, such as MTN, GLO, ECONET and ETISELAT. Furthermore, there were policy reforms in the banking sector - recapitalisation exercise of 2005 which influence the growth of the sector. All of these contributed to the sharp rise in the growth of the service sector. In the light of the impressive growth of the service sector in recent times and in spite of the importance of the service sector to macroeconomic variables (such as economic growth, employment, trade, foreign earnings etc.), previous studies, such as (Fajingbesi \& Odusola, 1999, pp. 137-179; Nworji \& Oluwalaiye, 2012; Olugbenga \& Owoye, 2007), have only worked on the link between government spending and economic growth, while the link between government expenditure and service sector growth was not examined.

Figure 1. Service sector output in Nigeria 1970-2017 (values in Naira, $\mathrm{Wb}$

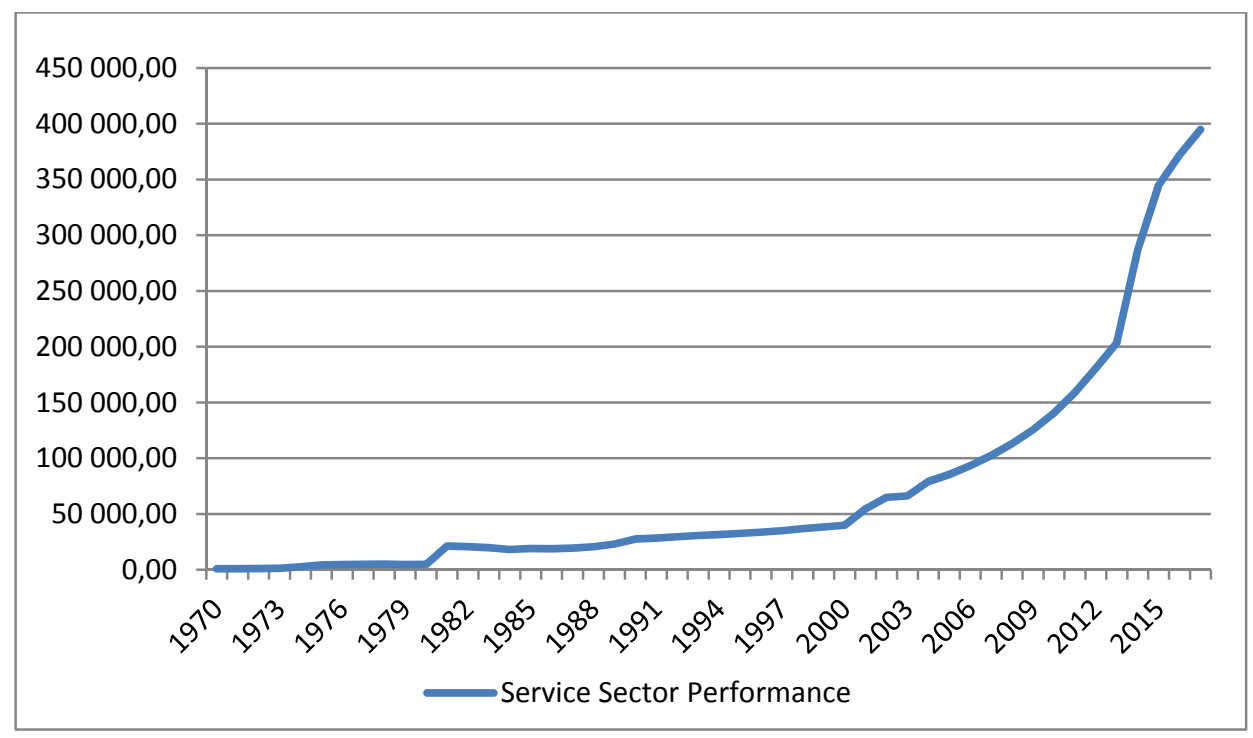

Source: Authors' computation using data from CBN Bulletin 2018 edition. Retrieved from www.cenbank.org

Beside the above, previous studies have also examined the issue of causality between economic growth and government spending; these studies argued that increase in economic growth can spur more expenditure from the government, while increase in government expenditure can also cause economic growth. The findings of the studies on the issue of causality have been inconclu- 
sive (Aregbeyen \& Kolawole, 2015; Gukar \& Ogboru, 2017; Rasaki, Hakeem, Ademoyewa, \& Bahir, 2014). Furthermore, none of the previous studies has examined the issue of causality with respect to government expenditure and service sector growth. It is against the above discussed issues that this study seeks to address the following research questions: (a) What is the impact of government (aggregate and specific) expenditure on service sector growth; and (b) what is the causal nexus between government expenditure and service sector growth in Nigeria. The lack of empirical literature on the link between service sector growth and government expenditure makes the issue worthy of examining.

This study is structured into five sections. Section one presents the introduction, section two discusses the literature review and section three discusses the research methods and procedure. Section four presents the research findings and discussion, while section five concludes the study.

\section{Literature review}

According to the Keynesian theorists, public expenditure promotes economic growth through multiplier effects of the aggregate demand. Aggregate demand is the sum of expenditures undertaken by the household, private business firms, government agencies and net exports (Jhingan, 2009). Increase in investment expenditures positively influences the growth of the economy given that the economy operates in the short run which is characterised by unemployed resources. However, the classical theorists hold that the economy operates in the long run and that government expenditure does not increase economic growth, but rather crowds-out private investment which further shrinks economic growth. The Recardian theorist holds that while government expenditure may influence economic growth in the short run, its impact in the long run is neutral (Jhingan, 2009). Other theories, such as the Bureau Voting Theory, suggest that the main driver of public sector expansion is artificial demand for government services created by self-interested government employees (Niskanen, 1971), while the Fiscal illusion theory tries to explain government growth by linking convoluted tax systems to the masking of the costs of public goods.

With respect to empirical literature, Charles, Onuchuku, \& Tamuno (2018) examined the impact of government expenditure on transport and communication, construction on economic growth in Nigeria over the period 1980 and 2016. The study used the Error Correction Modelling method and observed that government expenditure on construction, transport and communication is neg- 
atively related to economic growth. Ehigiator (2017) appraised the performance of the service sector in Nigeria. The study noted that in the last 15 years, the service sector has contributed meaningfully to economic growth, trade and employment. The study also noted that the issue of lack of investment and inadequate infrastructural facilities constitutes serious impediments to the growth of the service sector. Gukar \& Ogboru (2017) examined the relationship between government expenditure and economic growth in Nigeria over the period 1981 to 2016. The study decomposed government expenditure into capital and recurrent expenditure. The results of the study showed that administrative recurrent expenditure had positive and significant impact on economic growth, while the components of capital expenditure had insignificant impact on economic growth. Ojong, Ekpo, \& Anthony (2016) studied the relationship between government expenditure and economic growth in Nigeria. The findings of the study showed that both recurrent expenditure and capital expenditure significantly influenced economic growth.

Dada (2013) examined the composition effect of government expenditure on private consumption and economic growth in Nigeria. The study observed that government expenditure had long-run effect both on private consumption and output. Moreover, the study observed that government spending on social security, health and education had crowd-in effect on private consumption, while other components of government spending, such as administration, construction, agriculture, transport and communication, had crowd-out effect on private consumption. Laokulrach (2013) examined the impact of fiscal and monetary policies on service sector employment in Thailand. The study covered the period 1986 to 2011, and the findings of the study showed that socio-economic factors and supply side policies influenced employment in the service sector, while fiscal and monetary policies had no influence on employment in the service sector. Nworji \& Oluwalaiye (2012) examined the impact of government spending on road infrastructure on economic growth in Nigeria. The findings of the study revealed that transport and communication, including defence, had significant impact on economic growth.

Loto (2011) examined the effect of sectoral government expenditure on economic growth in Nigeria. The study applied Johansen co-integration and error correction model techniques. The results of the study showed that in the short run government expenditures on agriculture and education had negative impact on economic growth. In addition, Ighodaro \& Okiakhi (2010) examined the relationship between disaggregated government expenditure and economic 
growth in Nigeria. The study observed that government expenditure on health, national security, transportation, and communication had positive but insignificant impact on economic growth.

Earlier study by Liu, Hsu, \& Younis (2008) examined the nexus between public expenditure and economic growth in the United States during the period 1947-2002. The causality results revealed unidirectional causation from government expenditure to economic growth. The study also noted that public expenditure positively influenced the US economic growth. In Thailand, Komain \& Brahmasrene (2007) examined the relationship between government expenditure and economic growth. The results of the study showed the absence of cointegration between government expenditure and economic growth, while the causality estimate revealed unidirectional causality from government expenditure to economic growth. Focusing on a group of thirty OECD countries, Olugbenga \& Owoye (2007) examined the link between government expenditure and economic growth over the period 1970-2005. The results of the regression estimate showed a long-run relationship between government expenditure and economic growth. However, the causality estimate showed a unidirectional causality from government expenditure to economic growth for sixteen countries, thereby supporting the Keynesian hypothesis, while a unidirectional causation was also observed from economic growth to government expenditure for ten countries, confirming the Wagner's law. Finally, the causality estimate observed bi-directional causality between government expenditure and economic growth for a group of four countries.

The review of the empirical literature showed that while studies exist on the link between government expenditure and economic growth, only a few examined the extent to which government expenditure has influence on the growth of the service sector with particular reference to Nigeria. In this wise, this study attempts to bridge the gap by examining the relationship between government expenditure and service sector growth in Nigeria over the period 1970 to 2017.

\section{Research methods and procedure}

\subsection{Theoretical framework and model specification}

The study rests on Keynesian theory as the theoretical framework. The theory strongly emphasises that government expenditure positively influences the economic growth through the multiplier effect. Thus, this study to examine the 
relationship between government expenditure (GE) and service sector growth (SSG). This study specifies two models: Model 1 focuses on the impact of government expenditure on service sector growth, while Model 2 analyses the causal nexus between government expenditure and the growth of the service sector. With respect to the first objective and based on the Keynesian theoretical perspective, this study specifies the model below.

Linear equation (1)

$$
\mathrm{SSG}=\mathrm{f}(\mathrm{GE})
$$

$$
\mathrm{SSG}_{\mathrm{t}}=\delta_{0}+\delta_{1} \mathrm{GE}_{\mathrm{t}}+\varepsilon_{\mathrm{t}}
$$

Introducing other control variables that have been shown in the literature to have significant influence on the service sector growth, such as domestic interest rate (INR), domestic investment (DIN) and foreign direct investment (FDI) (Charles et al., 2018; Nworji \& Oluwalaiye, 2012), then equation (1) becomes:

$$
\mathrm{SSG}_{\mathrm{t}}=\delta_{0}+\delta_{1} \mathrm{GE}_{\mathrm{t}}+\delta_{2} \mathrm{FDI}_{\mathrm{t}}+\delta_{3} \mathrm{INR}_{\mathrm{t}}+\delta_{4} \mathrm{DIN}_{\mathrm{t}}+\varepsilon_{\mathrm{t}}
$$

To examine the causal nexus between government expenditure and service sector growth, the causality model below is specified:

$$
\begin{aligned}
\mathrm{SSG}_{\mathrm{t}} & =\sum_{i=1}^{p} \alpha_{11} \mathrm{SSG}_{\mathrm{t}-\mathrm{i}}+\sum_{i=1}^{p} \alpha_{12} G E_{t-i}+\mu_{1 t} \\
\mathrm{GE}_{\mathrm{t}} & =\sum_{i=1}^{p} \alpha_{21} \mathrm{SSG}_{\mathrm{t}-\mathrm{i}}+\sum_{i=1}^{p} \alpha_{22} G E_{t-i}+\mu_{2 t}
\end{aligned}
$$

Where $\mathrm{SSG}_{\mathrm{t}}$ refers to service sector growth and $\mathrm{GE}_{\mathrm{t}}$ refers to government expenditure.

\subsection{Measurement of variables}

The service sector growth (SSG) is measured by the output of the service sector (which comprises of the various sub-sectors (a) Transport, (b) Information and Communication, (c) Utilities, (d) Accommodation and Food Service, (e) Finance and Insurance, (f) Real Estate, (g) Professional, Scientific and Technical Service, (h) Administrative and Support Service, (i) Public Administration, 
(j) Education, (k) Human Health and Social Service, Arts, (1) Entertainment and Recreation and (m) other Services. Government Expenditure (GE) is measured by aggregate government expenditure and government expenditure on the service sector. Interest rate (INR) is measured by short term interest rate, otherwise known as the monetary policy rate; Domestic Investment (DIN) is measured by gross fixed capital formation, and Foreign Direct Investment (FDI) is measured by aggregate inflow Foreign Direct Investment. The study utilised annual data for the period 1970 to 2017. The data used for this study are real data adjusted for inflation, and are sourced from the Central Bank of Nigeria (CBN) statistical bulletins 2010 and 2018 editions.

\section{Research findings and discussion}

\subsection{An overview of the service sector in Nigeria}

The Nigerian service sector has metamorphosed from a poor performing sector to a fast growing and efficient sector. Since independence, the sector has been neglected for the agricultural sector before the discovery of oil and for the oil sector after the discovery of oil. Furthermore, the level of private sector investment in the sector can be described as low, accounting for the low contribution of the sector to economic growth. However, with the change in political administration from military to democratic dispensation in 1999, the Obasanjo administration, engaged in massive reforms in the service sector, particularly the transport and telecommunication, banking and finance, tourism and entertainment and recreation. The reform in the transport and communication sector brought about the demise of the Nigerian Telecommunications Limited (NITEL) and the establishments of private telecommunication firms, such as ECONET now AIRTEL, MTN, GLO and ETISELAT now 9MOBILE. Furthermore, the recapitalisation reforms in the banking and other non-banking institutions brought about improved performance in the financial sector. Similar impressive growth was also witnessed in the entertainment and recreation sub-sector. These reforms were responsible for the progressive contribution of the service sector to real gross domestic product from $28.3 \%$ in 2000 to $36.4 \%$ in 2017 . The effect of the above reforms is evident in Figure 2 below as indicated by the sharp increase from 2002 to 2017. It is also evident in Figure A1 (Appendix) that the reforms enhanced the growth of the service sector compared to the growth of the real gross domestic product. In comparing the share of the service sector in Nigeria 
with selected countries of the World, Table A1 (appendix) shows that the share of the service sector to GDP in most developed countries (with the exception of China) is above $70 \%$, while the share of the service sector to GDP for most developing countries is below $50 \%$.

Figure 2. Share of the service sector in real gross domestic product

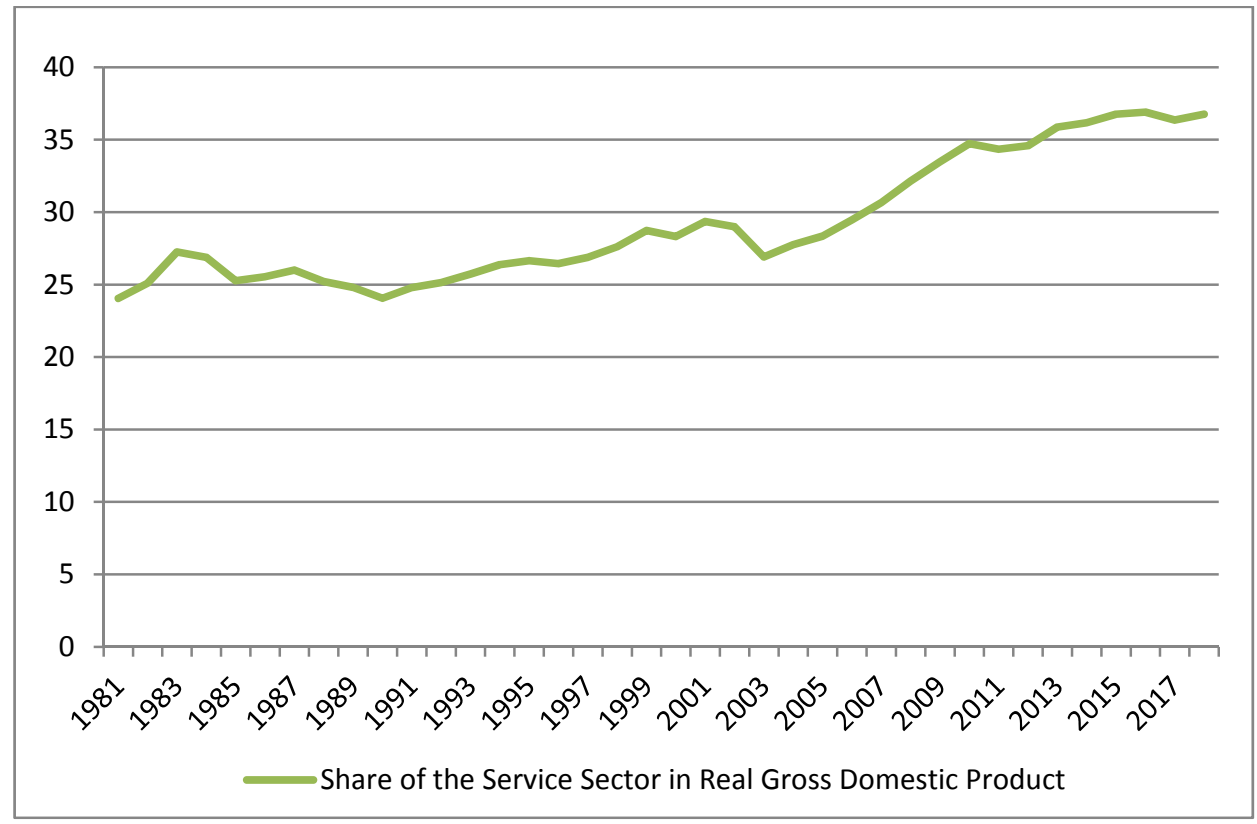

Source: Authors' computation using data from CBN Bulletin 2018 edition. Retrieved from www.cenbank.org

\subsection{Unit root test}

In order to put the analysis in proper perspective and avoid spurious regression estimate, this study conducts the unit root test using the Augmented Dickey Fuller test and the result is presented in Table 1. The unit root test shows that all the variables were integrated of order one, indicating that the variables were I(1) variables. This also suggests the need for co-integration test among the variables. 
Table 1. Unit root test

\begin{tabular}{|l|c|c|c|}
\hline \multicolumn{4}{|c|}{ Augmented dickey-fuller (ADF) test } \\
\hline Variables & Level & After Differencing & Status \\
\hline LSSG & 0.1159 & $-6.8043^{*}$ & $\mathrm{I}(1)$ \\
\hline LGES & -1.9372 & $-7.3657^{*}$ & $\mathrm{I}(1)$ \\
\hline LFDI & -0.6201 & $-6.6861^{*}$ & $\mathrm{I}(1)$ \\
\hline INR & -0.5627 & $-9.6265^{*}$ & $\mathrm{I}(1)$ \\
\hline LDIN & -2.3191 & $-7.1455^{*}$ & $\mathrm{I}(1)$ \\
\hline
\end{tabular}

Note: LSSG denote Log Service Sector Output; LGS denote Log of Government Expenditure; LGES denote Log of Government Expenditure on Service Sector; LFDI denote Log of Foreign Direct Investment; INR denote Domestic Interest Rate and LDIN denote Log of Domestic Investment.

* denotes $1 \%$ critical values, respectively.

Source: Authors' computation using e-views 9.

\subsection{Co-integration estimate}

Sequel to the results of the unit root test showing that all variables were integrated of order one, the co-integration test was conducted using the Johansen co-integration technique and the result is presented in Table 2. The results of the Trace and Max-Eigen tests show the absence of co-integrating among the variables in equation 3 of section three. These results show the absence of any long run relationship between the variables in the model.

Table 2. Co-integration estimate

\begin{tabular}{|l|c|c|c|l|l|c|c|}
\hline \multicolumn{4}{|c|}{ Trace test } & \multicolumn{5}{c|}{ Max-eigen test } \\
\hline $\begin{array}{c}\text { Hypothesized } \\
\text { no. of EC(s) }\end{array}$ & Stat. values & Critical values & Prob. & $\begin{array}{c}\text { Hypothesized } \\
\text { no. of EC(s) }\end{array}$ & Stat. values & Critical values & Prob. \\
\hline None & 51.43 & 69.82 & 0.575 & None & 18.63 & 33.88 & 0.844 \\
\hline At Most 1 & 32.81 & 47.85 & 0.568 & At Most 1 & 17.14 & 27.58 & 0.568 \\
\hline At Most 2 & 15.66 & 29.80 & 0.736 & At Most 2 & 11.65 & 21.13 & 0.582 \\
\hline At Most 3 & 4.01 & 15.49 & 0.903 & At Most 3 & 4.01 & 14.26 & 0.858 \\
\hline
\end{tabular}

Source: Authors' computation using e-views 9.

\subsection{Causality estimate}

Table 3 presents the causality estimate between government expenditure and service sector growth with respect to equations (3) and (4). The pair-wise causality estimate showed no evidence of causation between aggregate govern- 
ment expenditure (LGE) and service sector growth (LSSG). This finding simply shows that government expenditure does not cause the service sector growth, while the service sector growth does not cause government expenditure. However, the causality estimate between government expenditure on service sector and service sector growth, showed unidirectional causation from service sector growth to government expenditure on the service sector, while no causation was observed from government expenditure on service sector to service sector growth. The finding of the study is in line with Aregbeyen \& Kolawole (2015) who observed the absence of causation between government spending and economic growth, but in contrast to Komain \& Brahmasrene (2007) and Olugbenga \& Owoye (2007).

Table 3. Pair-wise causality

\begin{tabular}{|c|c|}
\hline Null hypothesis $\left(\mathrm{H}_{0}\right)$ & F-statistics (probability) \\
\hline \multicolumn{2}{|c|}{ Causality between aggregate government expenditure and service sector growth } \\
\hline LGE does not granger cause LSSG & $0.7012(0.5018)$ \\
\hline LSSG does not granger cause LGE & $0.5584(0.5764)$ \\
\hline \multicolumn{2}{|c|}{ Causality between government expenditure on service sector and service growth } \\
\hline LGES does not granger cause LSSG & $2.1545(0.1330)$ \\
\hline LSSG does not granger cause LGES & $13.9171(0.0000)$ \\
\hline
\end{tabular}

Source: Authors' computation using E-views 9 (2019).

\subsection{Regression estimates on government expenditure and service sector growth in Nigeria}

Owing to the absence of co-integration among the variable in equation (3), the study presents the short run regression estimate between government expenditure and the service sector growth. From Table 4, it was observed that in the short run aggregate government expenditure had negative and significant impact on the growth of the service sector. The negative impact of government expenditure on the service sector growth, indicates that government expenditure has retarded rather than enhanced the growth of the service sector. In contrast, foreign direct investment at current (DLFDI) had positive impact on the growth of the service sector. Moreover, domestic interest rate (DINR) and domestic investment (DLDIN) had positive and significant impact on the growth of the service sector. Specifically, it is observed that a unit increase in foreign direct investment, domestic interest rate (DINR) and domestic investment (DLDIN) is expected to increase the growth of the service sector by $0.31,0.87$ and 1.38 units, respectively. 
Table 4. Regression estimate on aggregate government expenditure and service sector growth in Nigeria

\begin{tabular}{|l|c|c|c|c|}
\hline \multicolumn{1}{|c|}{ Variables } & Coefficients & Std. Error & t-Statistics & Prob. \\
\hline $\mathrm{D}(\mathrm{LGE})$ & -1.4414 & 0.6639 & -2.1711 & 0.0377 \\
\hline $\mathrm{D}(\mathrm{LFDI})$ & 0.3157 & 0.1480 & 2.1330 & 0.0409 \\
\hline $\mathrm{D}(\mathrm{INR})$ & 0.0873 & 0.0387 & 2.2558 & 0.0313 \\
\hline $\mathrm{D}(\mathrm{LDI})$ & 1.3517 & 0.7240 & 1.8671 & 0.0714 \\
\hline $\mathrm{D}(\mathrm{LDI}(-3))$ & -1.3804 & 0.6012 & -2.2959 & 0.0286 \\
\hline CoinEq(-1) & -0.2764 & 0.1059 & -2.6097 & 0.0138 \\
\hline R-squared & 0.9300 & \multicolumn{2}{|c|}{ Adjusted R-Squared } \\
\hline F-Statistics (Prob.) & $34.35(\mathrm{p}<0.05)$ & \multicolumn{2}{|c|}{ Durbin-Watson Stat. } \\
\hline
\end{tabular}

Note: $\mathrm{D}$ denotes the first difference of the variables.

Source: Authors' computation using e-views 9.

In addition to the above, the coefficient of multiple determination of the model (R-squared) showed that the explanatory variables jointly explain about 93 per cent of the variations in service sector growth, while the remaining 7 per cent of the variations in the growth of the service sector is explained by variables not included in the model. The result of the coefficient of multiple determination shows that the model has a good fit. In addition, the result of the Durbin-Watson Stat of 2.11 shows that the estimate of the model is relatively free from the problem of serial correlation and that the model estimate is appropriate and can be used to infer recommendation for the improve growth of the service sector.

Drawing from the regression estimates, it can be deduced that the negative and significant impact of government expenditure on the growth of the service sector suggests that the contribution of government expenditure towards the service sector has been counter-productive. This also reflects the lack of attention or perhaps the neglect of the other sectors of the economy by the Nigerian government. Over the years, the government has focused exclusively on the oil sector, while other sectors have been abandoned which is reflected by the regression estimate. Such neglect on the sector is shown by the lack of investment in the service sector infrastructure such as good and accessible road network (for the road transportation sub-sector), poor investment in railway construction, poor funding of the sea ways transportation channels. Moreover, the inadequate supply of electricity has adversely affected the growth of the service sector, particularly the telecommunication sector. All the above could be attributed to the negative and insignificant impact of government expenditure on the growth of the service sector. However, the improved growth of the service sector in recent 
times can be attributed to the presence of private firms in the service and also to the increased inflow for foreign capital in the service sector. This is also buttressed by the positive and significant impact of foreign direct investment on the growth of the service sector.

The positive impact of foreign direct investment (DLFDI) on the growth of the service sector can be attributed to the improved growth of the telecommunication sub-sector that has witnessed the inflow of foreign investment from the multination mobile companies, such as MTN, Etisalats, and Airtel, among others. The significant contribution of the domestic interest rate (INR) and domestic investment (LDIN) shows the competitiveness of interest rate in enhancing the growth of the service sector. The rate of interest has been on the rise and the positive relationship between interest and service sector growth shows that rising rate of interest influences the service sector positively. Finally, domestic investment also contributed to the growth of the service sector. With respect to the estimate on the relationship between government expenditure on the service sector and service sector growth, Table 5 shows that only domestic investment had positive impact on the growth of the service sector. Government expenditure on the service sector had insignificant impact on the growth of the service sector.

Table 5. Regression estimate on government expenditure on service sector and service sector growth in Nigeria

\begin{tabular}{|l|c|c|c|c|}
\hline \multicolumn{1}{|c|}{ Variables } & Coefficients & Std. Error & t-Statistics & Prob. \\
\hline D(LDIN) & 0.5987 & 0.2484 & 2.4105 & 0.0223 \\
\hline CoinEq(-1) & -0.2004 & 0.1461 & -1.3719 & 0.1803 \\
\hline R-squared & \multicolumn{3}{|c|}{ Adjusted R-Squared } & 0.9586 \\
\hline F-Statistics (Prob.) $139.91(\mathrm{p}<0.05)$ & \multicolumn{4}{|c|}{ Durbin-Watson Stat. } \\
\hline
\end{tabular}

Note: D denotes the first difference of the variables.

Source: Authors' computation using e-views 9.

Some diagnostic tests (Breusch-Godfrey Serial Correlation LM test and heteroscedasticity ARCH tests) were carried out to ascertain the validity of the regression estimates (Table 6). The tests show the absence of serial correlation in the estimates, this is because the probability values were greater than 0.05 . The results of the diagnostic tests show the appropriateness of the regression estimates. 
Table 6. Diagnostic test

\begin{tabular}{|lc|ll|}
\hline \multicolumn{5}{|c|}{ Breusch-Godfrey serial correlation LM test } \\
\hline F-Statistics & 0.5930 & Prob. F(2,39) & 0.5592 \\
\hline Obs*R-squared & 1.7288 & Prob. Chi-Square(2) & 0.4213 \\
\hline \multicolumn{5}{|c|}{ Heteroskedasticity test: ARCH } \\
\hline F-Statistics & 0.1153 & Prob. F(1,31) & 0.7359 \\
\hline Obs*R-squared & 0.1206 & Prob. Chi-Square(1) & 0.7283 \\
\hline
\end{tabular}

Source: Authors' computation using e-views 9 (2019).

\section{Conclusions}

\subsection{Research contribution}

This study contributes to the existing literature by examining the link between government expenditure and service sector growth in Nigeria for the period 1970 to 2017. Government expenditure was measured by both aggregate government expenditure and specific government expenditure on the service sector. It is important to analyse the direct and indirect impact of government expenditure on the growth of the service sector in Nigeria. The results of the study show that aggregate government expenditure had negative and significant impact on service sector growth in Nigeria, while specific government expenditure on the service sector had insignificant impact on the service sector growth. This indicates that government expenditure has not enhanced the growth of the service sector over the years. Furthermore, the causality estimate shows the absence of causation between aggregate government expenditure and service sector growth, but service sector growth had unidirectional causation to government expenditure on the service sector. The finding of the study is line with Aregbeyen \& Kolawole (2015) who observed the absence of causation between government spending and economic growth, but in contrast to Komain \& Brahmasrene (2007) and Olugbenga \& Owoye (2007).

\subsection{Research implication}

The implication of the findings of this study is that government expenditure over the years has not contributed positively to the growth of the service sector. Thus, the study recommends the need for completion of various abandoned and on-going infrastructural projects such as road construction, water provision and electrification projects, which are vital to the growth of the service sector. Second, the government can through the monetary authority issue directives to de- 
posit money in banks to give loans at a reduced interest rate to investors in the service sector. Such monitored loan can enhance the growth of the service sector. Third, there is the need to de-emphasise the focus of the government on the oil sector and address its efforts on the service sector which is the driver of modern economic growth as evident in China, Japan and Dubai.

\subsection{Research limitations and future works}

Given the statistical negative relationship between aggregate government expenditure and service sector growth, the study recommends the need for further empirical research on the impact of specific government expenditure on the growth of each sub-sectors of the service sector. The outcome of such a study would provide more details on the significance of government expenditure on each sub-sector in particular, and on the service sector as a whole.

\section{References}

Al-Yousif, Y. (2000). Does government expenditure inhibit or promote economic growth: Some empirical evidence from Saudi Arabia. The Indian Economic Journal, 48(2), 92-96.

Aregbeyen, O., \& Kolawole, B. O. (2015). Oil revenue, public spending and economic growth relationships in Nigeria. Journal of Sustainable Development, 8(3), 113-123. http://doi.org/10.5539/jsd.v8n3p113

CBN Bulletin 2018 edition. Retrieved from www.cenbank.org

Charles, D., Onuchuku, O., \& Tamuno, S. O. (2018). Government expenditure on construction, transport and communication and economic growth in Nigeria. International Journal of Scientific Research, III(2), 39-48. Retrieved from http:/journalijsr. com/content/2018/IJSR71.pdf

Cooray, A. (2009). Government expenditure, governance and economic growth. Comparative Economic Studies, 51(3), 401-418. https://doi.org/10.1057/ces.2009.7

Dada, M. A. (2013). Composition effects of government expenditure on private consumption and output growth in Nigeria: A single-equation error-correction modelling. Romanian Journal of Fiscal Policy (RJFP), 4(2), 18-34. Retrieved from https://www.econstor.eu/handle/10419/107949

Ehigiator, B. O. (2017). The service sector in Nigeria: An escalator for new economic growth (unpublished master's thesis). School of Economics and Management, Lund University, Lund, Sweden.

Fajingbesi, A. A., \& Odusola, A. F. (1999). Public expenditure and growth. A paper presented at a training programme on fiscal policy planning management in Nigeria, Organized by NCEMA, Ibadan, Oyo State. 
Gukar, B. T., \& Ogboru, I. (2017). An empirical analysis of government expenditure and economic growth in Nigeria. Journal of Economics and Development Studies, 5(4), 122-134. https://doi.org/10.15640/jeds.v5n4a11

Ighodaro, C. A. U., \& Okiakhi, D. E. (2010). Does the relationship between government expenditure and economic growth follow Wagner's Law in Nigeria? Annals of University of Petrosani Economics, 10(2), 85-198. Retrieved from https://core. ac.uk/download/pdf/26833187.pdf

Jhingan, M. I. (2009). Advanced economic theory. Delhi: Vrinda Publications.

Komain, J., \& Brahmasrene, T. (2007). The relationship between government expenditures and economic growth in Thailand. Journal of Economics and Economic Education Research, 8(1), 93-102.

Laokulrach, M. (2013). The impacts of fiscal and monetary policies on service Sector employment: A study of Thailand from 1986-2011. IPEDR, 61(8), 35-40. https:// doi.org.10.7763/IPEDR.2013.V61.8

Loto, M. A. (2011). Impact of government sectoral expenditure on economic growth. Journal of Economics and International Finance, 3(11), 646-652. Retrieved from https://academicjournals.org/journal/JEIF/article-abstract/56985495810

Liu, L. Ch.-H., Hsu, C., \& Younis, M. Z. (2008). The association between government expenditure and economic growth: The Granger causality test of the U.S. data, 1974-2002. Journal of Public Budgeting Accounting, Finance and Management, 20(4), 439-452. https://doi.org/ 10.1108/JPBAFM-20-04-2008-B002

Niskanen, W. (1971). Bureaucracy and representative government. New York: Aldine.

Nworji, I. D., \& Oluwalaiye, O. B. (2012). Government spending on road infrastructure and its impact on the growth of Nigerian economy. International Journal of Management \& Business Studies, 2(2), 24-30. Retrieved from http://www.ijmbs.com /22/nworji.pdf

Cali, M., Ellis, K., \& te Velde, D. W. (2008). The contribution of the services to development and the role of trade liberalization and regulation (Working Paper, No. 298). London: Overseas Development Institute (odi). Retrieved from: https:// www.odi.org/resources/docs/3482.pdf

Olugbenga, A. O., \& Owoye, O. (2007). Public expenditure and economic growth. New evidence from OECD countries. Retrieved from https://academicjournals.org/ journal/JEIF/article-full-text-pdf/ADE56E728287

Ojong, C. M., Ekpo, N. S., \& Anthony, O. (2016). Government expenditure and its implication on Nigerian economy. IOSR Journal of Humanities and Social Sciences (IOSR-JHSS), 21(1), 50-55. Retrieved from https://pdfs.semanticscholar.org/bfab /2048301644957475ffa933b88c2dd394cef6.pdf

Ranjan, K. D., \& Sharma, C. (2008). Government expenditure and economic growth: Evidence from India. The ICFAI University Journal of Public Finance, 6(3), 60-69.

Rasaki, K., Hakeem, B., Ademoyewa, G., \& Bahir, N. O. (2014). The impact of public sector spending on economic growth of Nigeria. Journal of Economics and Sustainable Development, 5(3), 216-224. Retrieved from https://www.iiste.org/Journals /index.php/JEDS/article/download/11015/11316 


\section{Appendix}

Figure A1. Growth of real GDP versus growth of Service Sector (2001 to 2017)

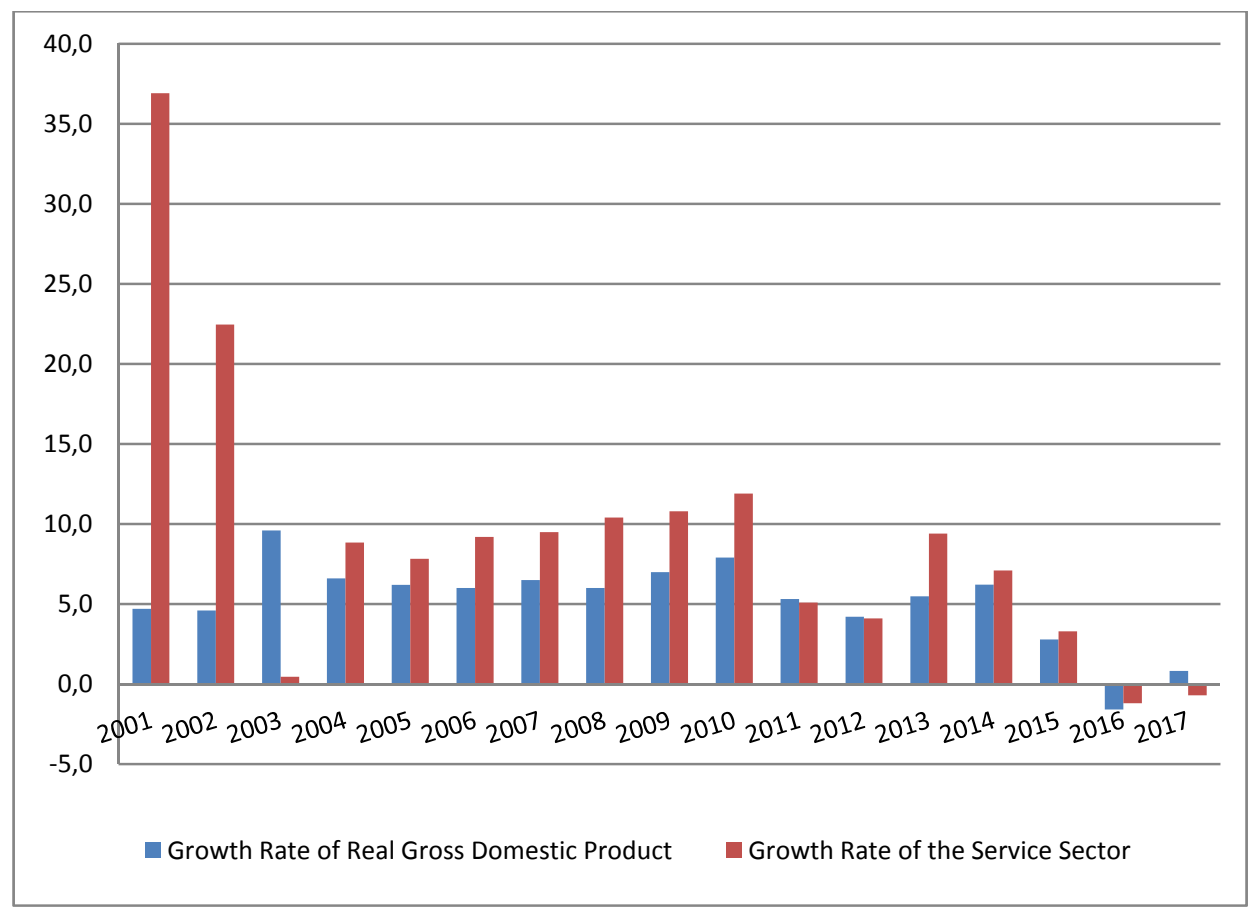

Table A1. GDP (PPP) Sector Composition (2017)

\begin{tabular}{|l|c|c|c|c|}
\hline \multirow{2}{*}{ Country } & \multirow{2}{*}{ Total GDP (PPP) (US\$MM) } & \multicolumn{2}{c|}{$\%$ Share of Sectors to GDP } \\
\cline { 3 - 5 } & & Agriculture & Industrial & Service \\
\hline China & $23,210,000$ & $7.9 \%$ & $40.5 \%$ & $51.6 \%$ \\
\hline United State & $19,490,000$ & $0.9 \%$ & $19.1 \%$ & $80.0 \%$ \\
\hline Japan & $5,443,000$ & $1.1 \%$ & $30.1 \%$ & $68.7 \%$ \\
\hline Germany & $4,199,000$ & $0.7 \%$ & $30.7 \%$ & $68.6 \%$ \\
\hline United Kingdom & $2,925,000$ & $0.7 \%$ & $20.2 \%$ & $79.2 \%$ \\
\hline France & $2,856,000$ & $1.7 \%$ & $19.5 \%$ & $78.8 \%$ \\
\hline Canada & $1,774,000$ & $1.6 \%$ & $28.2 \%$ & $70.2 \%$ \\
\hline South Africa & 767,200 & $2.8 \%$ & $29.7 \%$ & $67.5 \%$ \\
\hline Algeria & 630,000 & $13.3 \%$ & $39.3 \%$ & $47.4 \%$ \\
\hline Burma & 329,800 & $24.1 \%$ & $35.6 \%$ & $40.3 \%$ \\
\hline Kenya & 163,700 & $34.5 \%$ & $17.8 \%$ & $47.5 \%$ \\
\hline
\end{tabular}

Source: World Development Indicators. Retrieved from https://databank.worldbank.org/source/world-development -indicators 